\title{
Rural Development and River Flooding: The Case of Southern Ijaw, Bayelsa State, Nigeria.
}

\author{
${ }^{1}$ Ejenma, E., ${ }^{2}$ Emenike, G.C., ${ }^{3}$ Chikwendu, L., ${ }^{2}$ Taribi, A.S., ${ }^{1}$ Okeafor, M.O., \\ ${ }^{1}$ Ogbulafor, I.O., ${ }^{1}$ Alamu, O.N. and ${ }^{1}$ Obasi, O. \\ ${ }^{1}$ Federal College of Agriculture, Ishiagu, Ebonyi State. \\ ${ }^{3}$ Dept. of Geography \& Environmental Management, Imo State University, Owerri. \\ ${ }^{2}$ Dept. of Geography \& Environmental Management, University of Port Harcourt, Rivers State Nigeria.
}

\begin{abstract}
This study examined the state of rural development in a local government area whose most ravaging hazard is river flooding of the river Nun in Southern Ijaw area of Bayelsa State. As the second largest wetland in the world, the Niger Delta is a flat low-lying flood plain that is characterized by so many rivers and streams coupled with its closeness to the atlantic. The area is made up of about 57 villages as divided into 10 clans. A total of 9 villages were sampled while 402 households were chosen for questionnaire administration. Data analysis was aided by the simple linear regression (least square method) and percentage ratings on the respondents' perception on annual flooding. Results show that river flooding and income of the people have no significant relationship with $r^{2}$ value of 0.031. Also responses of the people titled to the fact that flooding has a more constructive than destructive effect in the area hence recommendation brings to light a need for further investigations to ascertain the profitability of approaches for effective development of settlements along the flood plains of the river Nun.
\end{abstract}

Keywords: Rural development, river Nun, flooding, Niger Delta.

\section{Introduction}

The relevance of rural areas to the development of any country is clearly evident in developing countries like Nigeria where greater percentage of the population engages in agriculture. This is due largely to the fact that rural areas to a reasonable extent are major sources of capital formation and principal markets for domestically manufactured goods and since they are agriculturally based, they form the main hub for the provision of raw materials to industries (Olatunbosun, 1975). Further, rural areas are the base for the production of food and fibre, being the foundation for any economic development.

Yet despite the importance attached to rural areas, they are characterized by a myriad of problems ranging from low per capita income, malnutrition and poor health to a general absence of infrastructure which are the means of improving the quality of life (Muoghalu, 1992). It is believed that numerous environmental problems play significant roles in the difficulties of developing the rural areas of the Niger Delta. Amazingly, the region is considered the mainstay of Nigeria's economy for its significantly high level of oil and gas reserves. Unfortunately, it is plagued with controversies, underdevelopment and a host of other environmental problems. Its natural terrain, climatic condition and hydrology all contribute to make it vulnerable to environmental hazards (NDES, 1997). The difficulty in the development of the Niger Delta region can only be blamed on the difficulty of the terrain (Udo, 1970).

However, with advanced technology, such regions could receive great transformation in development as can be noticed in most Benelux countries; Spain, France, Germany etc (Fellman, et al 2001).

In this striking context, flooding is one of the significant environmental problems that impinges on the development of the rural areas of Bayelsa State in particular and Niger Delta in general. This is by extension the case of Southern Ijaw which is one of the local government areas in Bayelsa State. Frequent blockages of channels by fallen trees and the deposition of transported materials and the generally low-lying nature of the terrain make it especially susceptible to seasonal to perennial flooding, siltation, occlusion and erosion (Niger Delta Development Master Plan, 2001). Most rural communities in Bayelsa State are crisscrossed by a maze of rivers and streams which are liable to annual flooding. Worse still is that most of the settlements are within the flood plains of these rivers thus, compounding the problem of rural development.

\section{The Problem}

As the second largest wet land in the world, the Niger Delta is a flat low-lying flood plain that is characterized by a number of rivers, rivulets, streams, canals and creeks. This makes it an area that is very vulnerable to river floods. Unlike other areas of the world where rivers occasionally overflow their banks, the 
rivers of the Niger Delta region such as the Nun, a major tributary of the river Niger annually overflows it banks to varying degrees causing serious environmental challenges for the rural communities around it. Etuonovbe (2011), reported that as a result of the overflow of the river Nun, approximately five thousand (5000) people were displaced from in and around Okorozi and Odi communities all in Kolokuma/Opokuma LGA of Bayelsa State. Also farmlands and crops were completely submerged. In these underdeveloped parts of the world, sophisticated monitoring and warning systems are completely lacking, the loss of lives and destruction of valuable infrastructure may be considerably lower compared to other parts of the world, the effects are still significant given the fact that the people are very dependent on the immediate deltaic flood plains for their socio-economic wellbeing.

The economies of rural communities are affected as they are greatly dependent on the natural resources of the region for their livelihood. Periods of high water surges could lead to disruption of several economic activities, food shortages, destruction of property and possible health implications (Benson, 2001). According to the Niger Development Master Plan (2001), approximately seven hundred thousand $(700,000)$ hectares of land are rendered useless due to annual floods.

\section{Study Area}

\section{Methodology}

Southern Ijaw lies within latitudes; $4^{0} 7^{\mathrm{N}}$ and $4^{0} 42^{\mathrm{N}}$ of the equator and longitudes; $5^{0} 58^{\prime} \mathrm{E}$ and $5^{0} 97^{`} \mathrm{E}$ of the Greenwich meridian with headquarters located in the town of Oporoma in the northern area. It has an area of $2,682 \mathrm{~km}^{2}\left(1.0355 \mathrm{~m}^{2}\right)$ with a population of 487,345 persons (NPC, 1991). Southern Ijaw bounds the atlantic ocean and has a coast line of about $60 \mathrm{~km}$ on the bight of Benin (fig.1). It is characterized by heavy rainfall with a short dry season usually between November and March. It lies on the tropical rainfall belt of Nigeria with extensive back swamps. The amount of rainfall is adequate for all year round crop production, and the wet season is not less than 340 days (Oku, 2003).

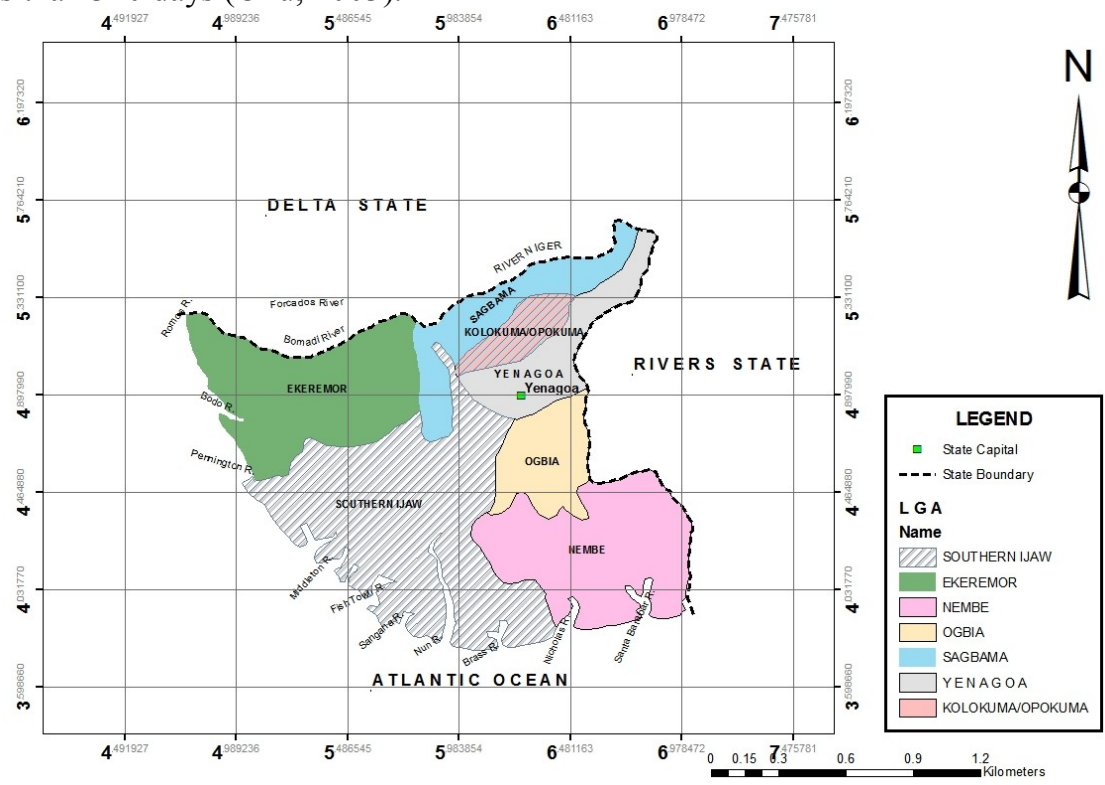

Fig.1. Study Area

\section{Sample and Sampling technique}

Southern Ijaw is made up of about fifty seven (57) villages and numerous ports that are divided into eight clans (fig.2). Ten percent (10\%) of the villages in each clan was included in the sample using the simple random sampling technique. Also $10 \%$ of the total number of households from each sampled village was selected. Households were then selected through systematic and semi-random sampling techniques after a sampling interval of five was added to the initial household. In essence, a total number of nine villages were sampled while four hundred and two (402) households were chosen for questionnaire distribution (Table.1) 


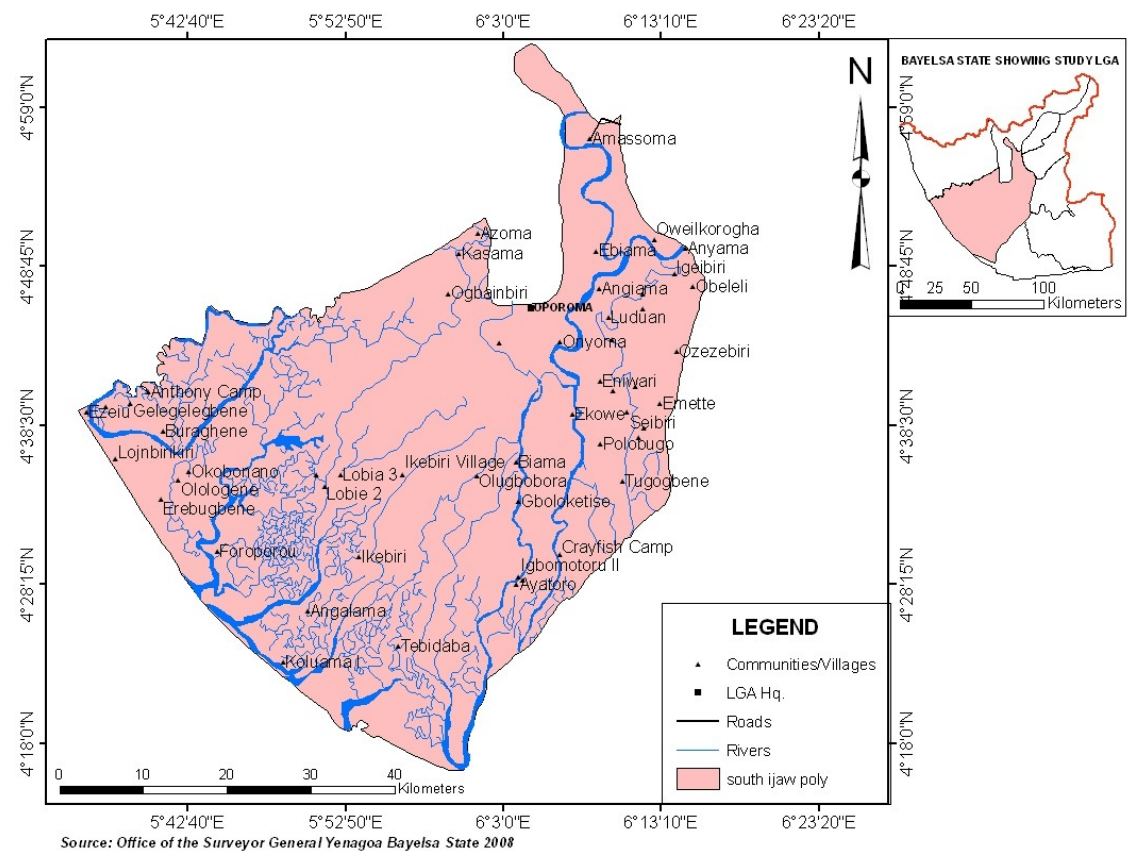

Fig. 2. Communities/Villages in Southern Ijaw

Table 1. Clans, villages and no. sampled.

\begin{tabular}{|l|l|l|l|l|l|}
\hline Clan & $\begin{array}{l}\text { Number of } \\
\text { villages }\end{array}$ & $\begin{array}{l}\text { Number } \\
\text { sampled }\end{array}$ & Sampled villages & $\begin{array}{l}\text { Number } \\
\text { households }\end{array}$ & of \\
\hline Boma & 18 & 2 & Ekowe /Polobubou & $532 / 208$ & 429 \\
Ogboin & 03 & 1 & Amatolo & 214 & $53 / 20$ \\
Tarakiri & 05 & 1 & Oweikorogha & 1544 & 21 \\
Oporoma & 06 & 1 & Angiama & 229 & 154 \\
Olodiama & 07 & 1 & Oyuma & 334 & 22 \\
Bassang & 10 & 1 & Okubie & 341 & 33 \\
Loluoama & 02 & 1 & Okoloama I & 236 & 34 \\
Akpoi & 06 & 1 & Ogboinbiri & & 23 \\
Total & 57 & 09 & & & 402 \\
\hline
\end{tabular}

Source: Authors' field work, 2012.

\section{Data Analysis}

Inferential statistical method was used in testing for a relationship between annual floods measured in terms of flood duration and income of the people. The simple linear regression (least square) was applied to model the relationship as follows:

$\mathrm{b}=\sum(\mathrm{x}-\mathrm{x})(\mathrm{y}-\mathrm{y})$

$$
\sum(\mathrm{x}-\mathrm{x})
$$

Where: $b=$ the regression coefficient

$\mathrm{x}=$ independent variable

$\mathrm{y}=$ dependent variable

Test for significance of the regression coefficient was done using the student's t distribution as follows;

$\sum=\quad \mathrm{r} \sqrt{ } \mathrm{n}-2$

$\sqrt{1-r^{2}}$

Where; $t-$ statistie

$\mathrm{r}=$ regression coefficient

$\mathrm{n}=$ number of sample

\section{Findings}

Table 2: Short Run Result of OLS for income (y) and flood duration (x) in Southern Ijaw LGA.

\begin{tabular}{lllll}
\hline Variable & Coefficient & Std. Error & t-statistic & Prob. \\
\hline $\mathrm{C}$ & 10146.19 & 30712.76 & 0.330357 & 0.7508 \\
$\mathrm{FD}$ & 92.34638 & 193.0843 & & 0.6470 \\
$\mathrm{R}^{2}$ & 0.031643 & & & \\
$\mathrm{R}^{2}$ adjusted & -0.106693 & & & \\
\hline
\end{tabular}


Rural Development and River Flooding: The Case of Southern Ijaw, Bayelsa State, Nigeria.

The above table reveals that Ho: is accepted at 0.05 level of significance since the critical t-value of 2.31 is greater than the calculated value of 0.48 . Also $r^{2}$ value of 0.031 was obtained suggesting that $3.1 \%$ unit variation in income is explained by a corresponding unit variation in flooding, hence it is not significant. The remaining $96.9 \%$ variation in income will be explained by other variables not captured in the model.

Table 3: Effects of flooding on Economic Activities

\begin{tabular}{|c|c|c|c|c|c|c|c|c|c|c|c|c|c|c|c|c|c|c|c|c|}
\hline & & \multicolumn{2}{|c|}{ Ekowe } & \multicolumn{2}{|c|}{ Polobubou } & \multicolumn{2}{|c|}{ Amatolo } & \multicolumn{2}{|c|}{ Oweikorogha } & \multicolumn{2}{|c|}{ Angiama } & \multicolumn{2}{|c|}{ Oyuma } & \multicolumn{2}{|c|}{ Okubie } & \multicolumn{2}{|c|}{ Koloama I } & \multicolumn{2}{|c|}{ Ogboinbiri } & \multirow[t]{2}{*}{ Total } \\
\hline & & No & $\%$ & NO & $\%$ & NO & $\%$ & NO & $\%$ & NO & $\%$ & NO & $\%$ & NO & $\%$ & NO & $\%$ & NO & $\%$ & \\
\hline \multirow[t]{3}{*}{ Farming } & Const & 12 & 30 & 4 & 21 & 7 & 27 & 6 & 40 & 33 & 33 & 7 & 39 & 8 & 39 & 9 & 29 & 5 & 38 & 91 \\
\hline & Destr. & 28 & 70 & 15 & 79 & 19 & 73 & 9 & 60 & 68 & 67 & 11 & 61 & 13 & 61 & 22 & 71 & 8 & 62 & 193 \\
\hline & Total & 40 & 100 & 19 & 100 & 26 & 100 & 15 & 100 & 101 & 100 & 18 & 100 & 21 & 100 & 31 & 100 & 13 & 100 & 284 \\
\hline \multirow[t]{3}{*}{ Lumbering } & Const & 14 & 67 & 9 & 75 & 13 & 59 & 8 & 89 & 36 & 90 & 7 & 100 & 6 & 60 & 18 & 100 & 9 & 81 & 120 \\
\hline & Destr. & 7 & 33 & 3 & 25 & 9 & 41 & 1 & 11 & 13 & 10 & Nil & Nil & 4 & 40 & Nil & Nil & 2 & 19 & 39 \\
\hline & Total & 21 & 100 & 12 & 100 & 22 & 100 & 9 & 100 & 49 & 100 & 7 & 100 & 10 & 100 & 18 & 100 & 11 & 100 & 159 \\
\hline \multirow[t]{3}{*}{ Fishing } & Const & 35 & 900 & 14 & 100 & 17 & 100 & 10 & 100 & 56 & 95 & 9 & 82 & 14 & 100 & 18 & 86 & 15 & 100 & 188 \\
\hline & Destr. & 4 & 10 & NII & NII & NIL & Nil & Nil & $\mathrm{Nil}$ & 3 & 5 & 2 & 18 & Nil & Ni1 & 3 & 14 & Nil & $\mathrm{Nil}$ & 12 \\
\hline & Total & 39 & 100 & 14 & 100 & 17 & 100 & 10 & 100 & 59 & 100 & 11 & 100 & 14 & 100 & 21 & 100 & 15 & 100 & 200 \\
\hline
\end{tabular}

The table above shows the perception of respondents in the sampled communities on the efforts of flood. In Amatolo, 73\% agreed that it is a destructive hazard on farming while others see it as being constructive with $27 \%$. In Oweikorogha community, $40 \%$ of respondents said it is beneficial to farming while the others see it otherwise. In Ogboinbiri, $69 \%$ is of the view that flooding is harmful to farming while others agree that it is beneficial.

On lumbering, about $67 \%$ of the respondents say it is beneficial in Ekowe while the other $33 \%$ agree that it is destructive. Respondents in Koloama I and Oyuma see it as being constructive on lumbering.

In the case of fishing, there is almost a general agreement in all the communities that floods which inundate the areas have a more constructive effect.

\section{Discussion and Conclusion}

Flooding is predominantly viewed as a destructive hazard whenever the soico-economic implications are assessed but constructive as it may be in this area, the study observed that the rich alluvial deposits on farmlands on annual basis contribute to the fertility of the soil, optimum for plant growth. This finding is consistent with the results of constructive effects of flooding in areas like the Nile and Ganges Delta where farmlands on the basin irrigation scheme receive rich alluvium which sustains most agricultural practices in the drought prevalent regions. Further, Bangladesh floods have also been cited as having significance to the economy and survival of its people through provision of water for crops and land fertility (Munna, 2007).

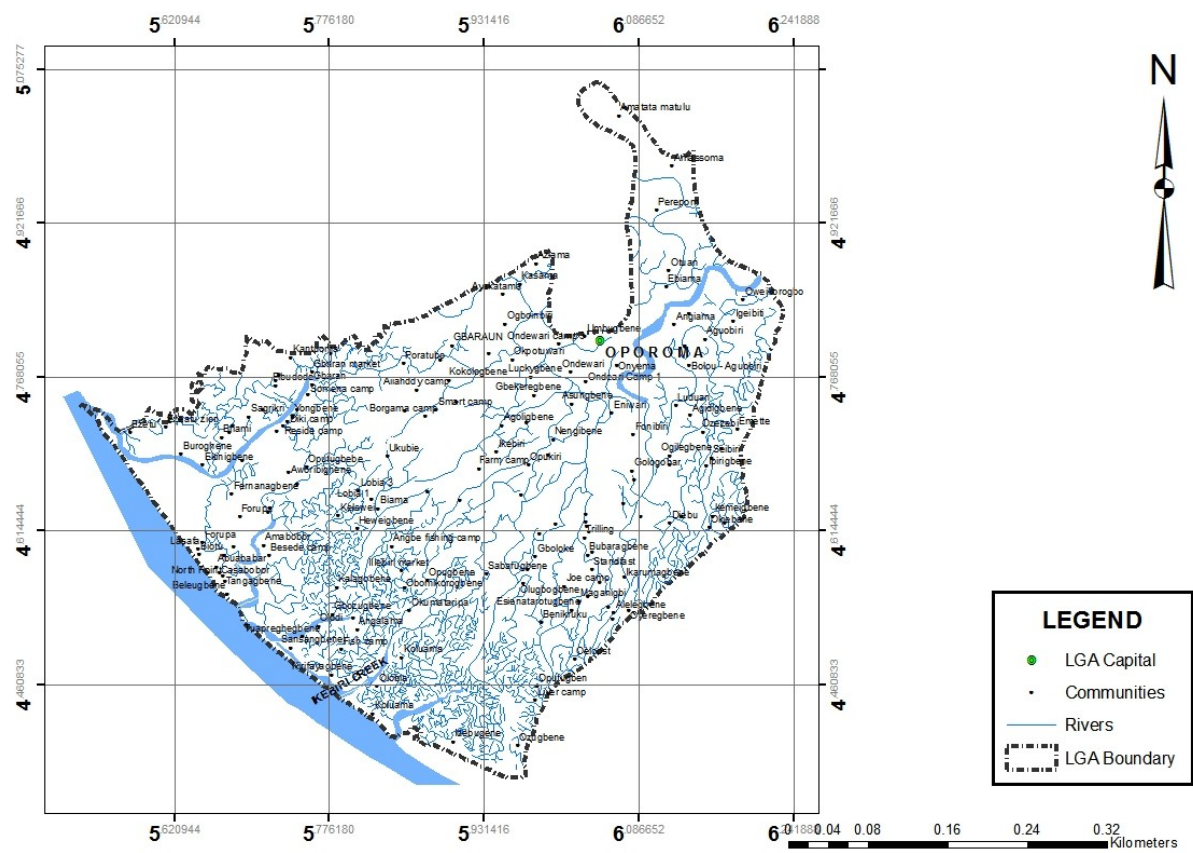

Fig. 3. Drainage of Study Area 
In essence, the result of this work has not all the same faulted rural development efforts on seasonal flooding of the river Nun in Southern Ijaw hence the economic transformation of the area will rather be enhanced if effective management options, albeit controlling free flooding from destroying human habitation and allowing it on farmlands to tap most of its beneficial effects.

\section{References}

[1]. Benson, T.D. (2007). Consequences of floods: a case study of Yenagoa city, Bayelsa being an unpublished B.Sc research project submitted to Dept. of Geography and Environmental Management, Niger Delta University, Bayelsa State.

[2]. Etuonovbe, A. K. (2011). Devastating effects of flooding in Nigeria. FIG working week, pg. 18 -22.

[3]. Fellman, J.D. Getis, A. \& Getis, J. (2001). Human Geography: landscapes of human activities. McGraw Hill, Boston.

[4]. Munna, T.I. (2007). Floods in Bangladesh: possible causes and solutions. Todays Magazine, USA.

[5]. Muogshalu, L.N. (1992). Rural development in Nigeria: A review of previous initiatives. In Olisa, S.O. and Obuikwu, J.I. (eds). Rural development in Nigeria. Dynamics and strategies. Mekslink publishers Nigeria ltd; Awka.

[6]. NDDC (2001). Niger Delta Development Master Plan 2001.

[7]. NDDC (1997). Niger Delta Environmental Survey 1997.

[8]. Oku, B.H. (2003). The Niger Delta environment: its local geography. Prelyn publishers, Port Harcourt.

[9]. Olatunbosun, D. (1975). Nigeria's neglected rural majority. Oxford University press, Ibadan.

[10]. Udo, R.K. (1970). Geographical regions of Nigeria. University of California, California. 